\title{
Analysis of the data collection and processing system for assessing the actual reliability of domestic tractors exemplified by PJSC "Promtractor"
}

\author{
Olga Vyacheslavova ${ }^{1, *}$, Irina Parfenyeva ${ }^{1}$, Tatyana Levina ${ }^{1}$, and Anatoly Klochkov ${ }^{2}$ \\ ${ }^{1}$ Moscow Polytechnic University, 107023 Moscow, Russia \\ ${ }^{2}$ Ryazan State Agrotechnological University Named after P.A. Kostychev, 390044 Ryazan, Russia
}

\begin{abstract}
The analysis of statistical parameters for the production of agricultural machinery and parameters characterizing the reliability and quality of domestic tractors is carried out. It is shown that the organization of a system for collecting and processing information on the reliability of products is important from the point of view of quality and reliability of tractors. The experience of creating such a system is considered as exemplified by PJSC "Promtractor".
\end{abstract}

\section{Introduction}

Russia is the country with the largest agricultural land in the world. In this regard, the level of mechanization of the domestic agricultural sector and the prospects for the development of agricultural machinery production are very relevant.

In general, the situation in the industry remains very ambiguous. There is still a lot of obsolete machinery in fields. A significant part of agricultural machinery is operated more and longer than expected. The situation with Russian agricultural machinery could have been much better.

Let us consider some statistical factors. According to Rosstat (Federal State Statistics Service) for 2018, 7,836 tractors were produced in Russia and this is $3.3 \%$ less compared to 2017. They included 6,728 agricultural tractors $(-4.8 \%)$ and 1,108 industrial tractors $(+6.3 \%)$. The share of domestic brands in the total number of tractors produced in Russia in 2018 was only $46.0 \%$, and foreign brands of the Russian assembly accounted for $54.0 \%$, which included assembly of components from Minsk Tractor Plant $-30.7 \%$ and assembly of foreign components (Versatile, New Holland, Agrotron, Axion, John Deere, Xerion) $-21.5 \%$.

Despite the general decline, according to the results of 2018, an increase in production at a number of enterprises of the Russian Federation was noted. For example, the Ural Road Construction Equipment Plant showed a positive development trend $(+72.1 \%)$, "Rostselmash" Combine Plant (+ $14.2 \%)$, Petersburg Tractor Plant $(+14.2 \%)$, Cherepovets Casting and Mechanical Plant (+ $18.8 \%$ \%), PJSC "Promtractor" $(+8.3 \%)$, etc. As a result, in 2018 all manufacturers shipped $11 \%$ more tractors than a year earlier, so 8,495 units of agricultural machinery were shipped.
In 2018, combine harvesters produced 5,099 units (29.9\% less) which included 1,116 combines of foreign brands. Shipment of combine harvesters decreased by $12.3 \%$ compared to the corresponding period last year. 5,526 pieces of equipment were shipped. Shipment of forage harvesters increased by $7.4 \%$ compared to the corresponding period of the previous year, so 753 pieces of equipment were shipped. Their production grew by $12.6 \%$. In total, 776 units were produced, of which 123 units were foreign brands combines. Figure 1 shows the presence of agricultural machinery in the agricultural sector of the Russian Federation at the end of May 2019.

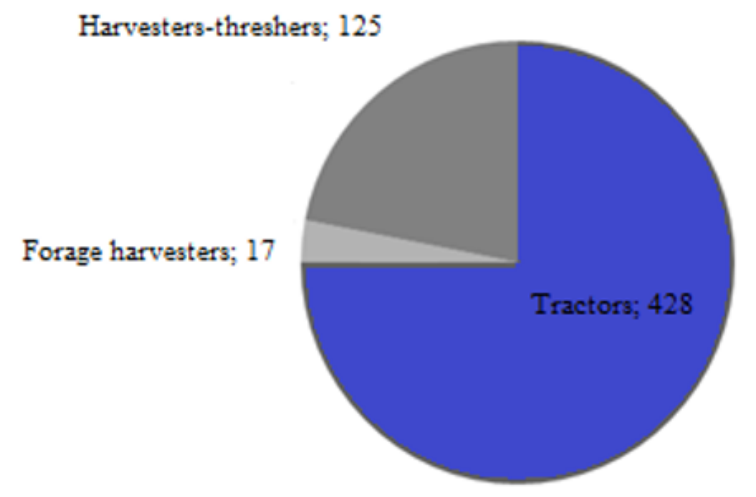

Fig. 1. Agricultural machinery in the agro-industrial complex of the Russian Federation at the end of May 2019, thousand units

If we talk about the modernization of the domestic agro-industrial complex (AIC) as a whole, the situation is still not simple. It is important not to stop at record yields. According to the Russian Ministry of Agriculture, the number of tractors and combine harvesters working in the fields has tripled compared to 1990. The area of arable land has decreased by about $12 \%$ for 17 years.

* Corresponding author: vyache-smis@ mail.ru 
Thus, the load on a unit of equipment has grown significantly.

According to the forecast of the Ministry of Agriculture of Russia, the volume of deliveries of agricultural machinery to the domestic market of Russia will increase from 107.4 billion rubles in 2020 to 183.2 billion rubles in 2024, Fig. 2 .

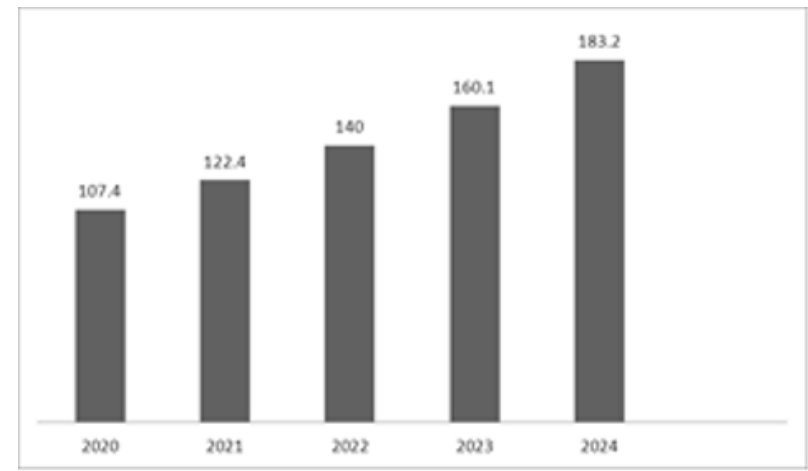

Fig. 2. Forecast of deliveries of agricultural machinery to the Russian market in value terms, billion rubles

However, it should not be forgotten that quantity does not always mean quality, and cheap is not the best. Nowadays the competition between domestic and foreign brands is more and more vivid. The cost of raw materials and energy tariffs are constantly growing, the tax policy is stiffening and loans remain prohibitively expensive. These and other unsolved problems lead to the creation of unequal conditions for competition between Russian and foreign companies.

As a result, Russian manufacturers of agricultural machinery are not sufficiently competitive at the domestic market. In fact, while maintaining current industry trends, the country's food security may be directly dependent on the import of machinery.

Focusing on the highest rates in production and creating a streamlined mechanism that responds to changes in market requirements, should become a strategic direction for the development of a modern engineering enterprise in the Russian Federation.

Important from the point of view of improvement of quality and reliability of the let-out equipment is the organization at the enterprise of system of collecting and processing of information on reliability of let-out production [1]. The system of collecting and processing information about reliability allows:

- identify design and technological shortcomings of the product, reducing its reliability, as well as shortcomings in the organization of repair and operation;

- install elements and components that limit the reliability of the product;

- to clarify the criteria of failures and norms of consumption of spare parts;

- to assess the effectiveness of measures to improve the reliability of products.

\section{Reliability analysis}

In relation to tractor equipment, reliability is the most important technical and economic characteristic that determines the cost and quality of manufacturing, maintenance, repair and use of the machine.

If one compares domestic tractors with foreign ones in similar conditions, then the reliability of most models of Russian tractors, especially powerful ones, in the initial period of operation is significantly (up to 3 times) lower than that of foreign tractor equipment. Therefore, the integrity of data on an objective assessment of the actual reliability of serviceable equipment, which can be obtained on the basis of tests and surveys under comparable operating conditions at farms of specific soil and climatic zones, including observations and examinations at machine test stations (MTS) and in regional service centers (RSC) are of paramount importance).

Reliability analysis of domestic tractors is carried out in [2-4] and others. The available information on reliability of manufacturers of foreign tractor equipment is fragmentary and almost absent in periodicals. Figures 3-6 show comparative data on reliability parameters of domestic tractors and their foreign counterparts [4]. Comparison is made for the most common wheeled tractors of the classic all-wheel drive $4 \mathrm{~K} 4 \mathrm{a}$ layout diagram and articulated frame of the $4 \mathrm{~K} 4 \mathrm{~b}^{\prime}$ diagram. These layout diagrams are typical for high power tractors in the range from 270 to $435 \mathrm{HP}$, developed in Russia and abroad in recent years and widely used in agricultural production.

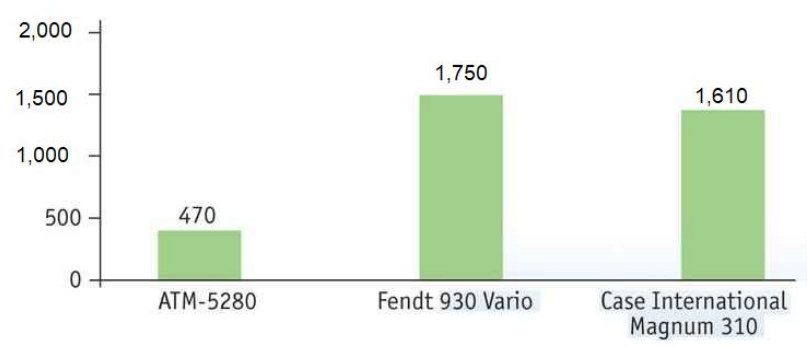

Fig. 3. Trouble-free life of single $4 \mathrm{~K} 4 \mathrm{a}$ tractors, including the average one of the batch for a test run of 1,000 moto-h according to the results of tests at MTS

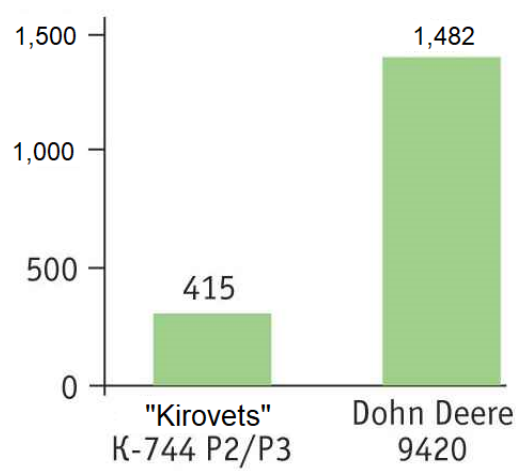

Fig. 4. Trouble-free life of single $4 \mathrm{~K} 4 \mathrm{~b}$ tractors, including the average one of the batch for a test run of 1,000 moto-h according to the results of tests at MTS

There is also data on the reliability of individual tractor units. Studies showed that the main causes of failures during the warranty period of operation of automotive engines were: the quality of manufacture and assembly of new ones - 35-55\%; repair quality - 
50-70\%; constructive imperfection - up to $10 \%$ and violation of operating rules $-20-60 \%$.

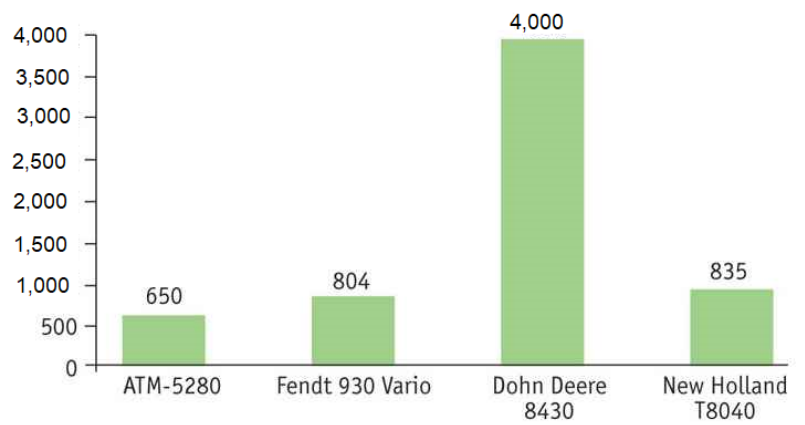

Fig. 5. Estimated mean operating hours for a complex failure of $4 \mathrm{~K} 4 \mathrm{a}$ tractors for a control run of 1000 moto-h according to the results of one-time examinations (for Fendt 930 Vario tractor, the average operating time per batch taking into account operational failures is given)

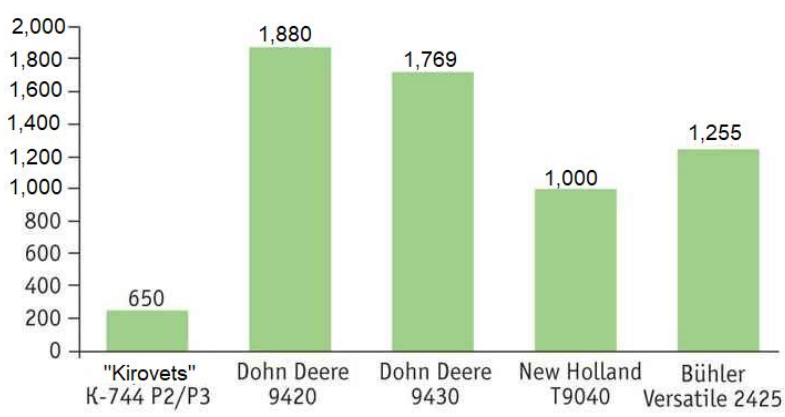

Fig. 6. Estimated mean operating hours for the complex failure of $4 \mathrm{~K} 4 \mathrm{~b}$ tractors for the control running hours of 1000 moto-h according to the results of single examinations

The largest number of failures was noted in the fuel supply system $(27.3 \%)$ and in units: cylinder block $(18.9 \%)$, cylinder head $(12.7 \%)$, and the highest failure rate of new and repaired engines occurred in the first 100-300 hours' work. Frequent failures during the warranty and post-warranty periods of operation include the following defects: increased wear of the main and connecting rod liners $(28-32 \%)$, clutch defects (up to $20 \%)$, turbocharger defects $(7.6 \%)$, increased wear on sleeves and pistons $(6.75 \%)$.

Reasons for failure may be:

1) Design errors and deficiencies: insufficient strength of individual elements or structures; failed node layout; low technological design related to the implementation of blanks, mechanical and heat treatment, assembly; insufficient protection of the structure from dust, moisture, etc.

2) Manufacturing failures: latent defects (shells, friability, foreign inclusions, material heterogeneity), violations of manufacturing and assembly technology, etc.

3) Improper operation and maintenance - failure to comply with operating instructions, non-observance of maintenance rules due to low qualification of staff, etc.

4) External factors: high or low temperature, humidity, atmospheric pressure, air pollution, etc.

5) Poor repair: poor control of the repair, mismatch of the material, manufacturing technology (accuracy and quality of processing) and assembly to the original manufacturing conditions.

Knowing the reliability parameters, the consumer can not only evaluate the performance of the machine and on this basis determine the feasibility of its acquisition, but also solve many economic and engineering problems associated with maintenance and repair of machines. These tasks include:

- planning the total number of repairs of machines and operating time of machines before repair;

- calculation of average technical resources of machines (elements) and their finished operating time;

- forecasting the residual resources of parts and interfaces of machines during their operation or repair;

- calculation of the number of operational failures of machines and determination of the cost of their elimination, etc.

\section{Experience in organizing a system for collecting and processing information on the reliability of products in PJSC "Promtractor"}

A number of organizations collect, process and analyze information on failures and malfunctions of equipment manufactured by PJSC "Promtractor".

1) The specialized company of Concern "Tractor Plants" "Service Industrial Machines LLC" (Service IM LLC) organizes warranty and post-warranty maintenance and repair of all equipment manufactured by the holding enterprises and sold by its trading companies "CHETRA - Industrial Machines", "Agromashholding" and " ChKZCh". The company regularly provides free training for operators and service engineers, both consumers and service organizations, provides customers with spare parts and consumables throughout the product life cycle.

2) LLC "Agromashholding" is a specialized company engaged in the supply and warranty service of machines, assemblies, attachments. The company has created a special department for warranty service of equipment.

3) The head unit of PJSC "Promtractor" for the collection of information, analysis and reporting on reliability is the Bureau of Reliability and Supervised Tests (BR\&ST) of the Technology Audit Service (TAS).

4) A network of RIC organized by PM Service LLC for warranty technical maintenance and repair of equipment, the main task of which is to obtain information from the final user.

Information on the reliability of tractors is collected throughout the entire observation period until the limit state of the tractors is reached by the methods of constant (controlled) observations, periodic observations and onetime inspections. The moment of selecting serial tractors with an operating time of not more than 200 moto-h for observations is considered as the beginning of observations in actual operation.

On the basis of domestic practice, methods for determining the technical condition of agricultural machinery have been developed and successfully used 
$[6,7]$, which allow to determine the main indicators of the technical condition of machinery associated with such characteristics of its functioning as operating time, wear and deviations of machine parts parameters.

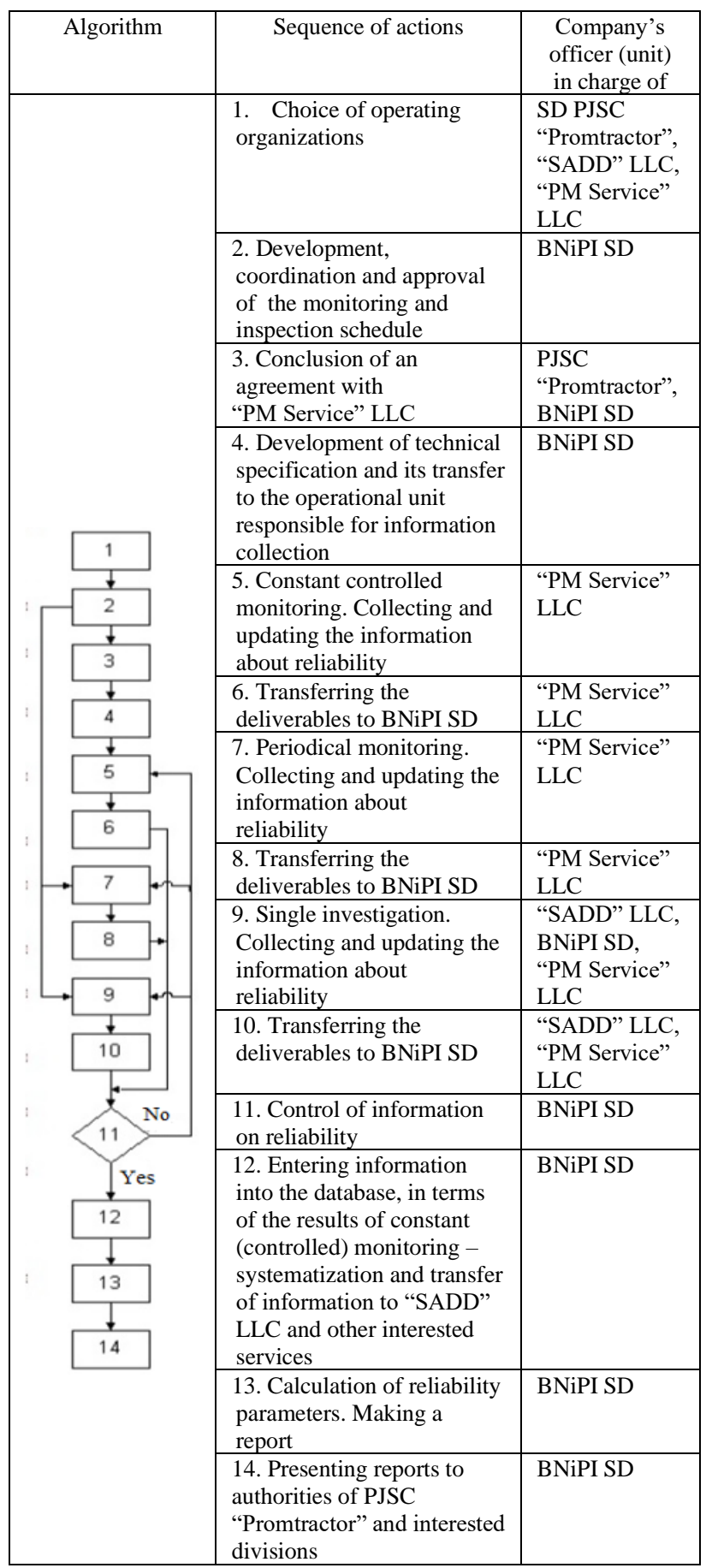

Fig. 7. Algorithm for organizing surveys and collecting information on the reliability of tractors

The algorithm for collecting, processing and analyzing information about failures and malfunctions of tractors is presented in Figure 7.

The procedure for identifying "problematic" components and assemblies of industrial tractors is presented in Table 1.
Information about defects and malfunctions comes to PJSC "Promtractor" in various forms. This information is summarized in tables, in which, upon receipt (calendar terms), the received data on defects and malfunctions is entered.

Primary information is subject to preliminary control in order to verify its completeness and reliability, compliance with the established frequency of data presentation, identification and correction of the deficiencies and inaccuracies. Information received should be monitored as it becomes available, as at the same time, there are still more opportunities to obtain the necessary clarifications and additions from consumers upon request. It is not allowed entering information into the database that has not passed preliminary control.

Table 1. Stages of identifying "problem" units and assemblies of industrial tractors

\begin{tabular}{|c|l|}
\hline $\begin{array}{c}\text { Stages of } \\
\text { identifying } \\
\text { problematic } \\
\text { units }\end{array}$ & \multicolumn{1}{|c|}{ Sequence description } \\
\hline 1 & $\begin{array}{l}\text { Compilation of tables of defects and } \\
\text { malfunctions of tractors in order of receipt } \\
\text { from consumers }\end{array}$ \\
\hline 2 & $\begin{array}{l}\text { Systematization of defects and malfunctions } \\
\text { by types of complexity by tractor brands }\end{array}$ \\
\hline 3 & $\begin{array}{l}\text { Control of the received information and its } \\
\text { reconciliation with the received data and } \\
\text { data of past years }\end{array}$ \\
\hline 4 & $\begin{array}{l}\text { Development of forms of documents } \\
\text { describing failures and malfunctions of } \\
\text { tractors, as well as sources of defects and } \\
\text { their possible causes }\end{array}$ \\
\hline 5 & $\begin{array}{l}\text { Identification of problematic units and } \\
\text { assemblies in each type of tractor using } \\
\text { Pareto analysis }\end{array}$ \\
\hline 6 & $\begin{array}{l}\text { Systematization of defects and malfunctions } \\
\text { of tractors by complexity groups (1, 2, 3 - } \\
\text { complexity groups) in order to formulate } \\
\text { requirements and methods of providing for } \\
\text { defective units and assemblies }\end{array}$ \\
\hline 7 & $\begin{array}{l}\text { Determining problematic units and } \\
\text { assemblies (with the greatest complexity of } \\
\text { defects) }\end{array}$ \\
\hline $\begin{array}{l}\text { Analysis of critical defects and malfunctions } \\
\text { indicating the nature of failures, their causes } \\
\text { and measures taken by the customer }\end{array}$ \\
\hline $\begin{array}{l}\text { Description of corrective actions to eliminate } \\
\text { the causes of discrepancies identified by the } \\
\text { customer }\end{array}$ \\
\hline $\begin{array}{l}\text { Preparing recommendations to eliminate } \\
\text { defects on the basis of an album of potential } \\
\text { defects and malfunctions of various units } \\
\text { and assemblies of tractors }\end{array}$ \\
\hline 8
\end{tabular}

Information on failures and malfunctions of tractors is recorded in the log-book of operating hours, failures and malfunctions. The form of the document is presented in Table 2. Based on this information, the next steps of the algorithm are carried out.

The data on defects and malfunctions at the initial stage are not systematized and not classified. Therefore, it is necessary to carry out a large amount of work in order to identify the "problem" units and assemblies. 
Analyzing the data obtained, problematic units and assemblies are identified, then they are diagramed and it presents visual assessment of the number of defects in various units and assemblies in both absolute and percentage terms.

Table 2. Log-book of operating hours, failures and malfunctions

\begin{tabular}{|c|c|c|c|c|c|c|}
\hline \# & 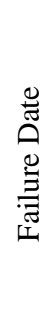 & 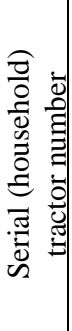 & 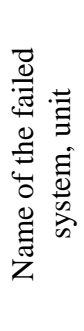 & 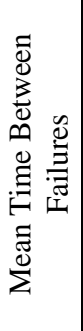 & 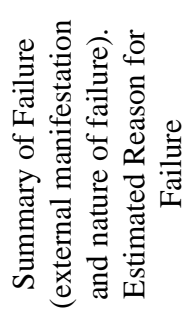 & 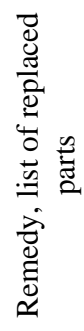 \\
\hline 1 & 2 & 3 & 4 & 5 & 6 & 7 \\
\hline \multicolumn{7}{|c|}{ Tractor model } \\
\hline & & & & & & \\
\hline & & & & & & \\
\hline
\end{tabular}

As an example, one can consider the defects of $\mathrm{T}-$ 11.01 tractor identified during the warranty period of operation, Table 3.

Table 3. Defects of $\mathrm{T}-11.01$ tractors identified during the warranty period

\begin{tabular}{|l|c|c|}
\hline \multicolumn{1}{|c|}{ Name of units } & $\begin{array}{c}\text { Number of } \\
\text { defects }\end{array}$ & $\begin{array}{c}\text { Difficulty } \\
\text { group }\end{array}$ \\
\hline Hydraulic Attachment & 83 & 1 \\
\hline $\begin{array}{l}\text { Electrical equipment and } \\
\text { devices }\end{array}$ & 60 & 1 \\
\hline Transmission & 45 & 3 \\
\hline Engine (ICE) & 42 & 2 \\
\hline Travel system & 18 & 1 \\
\hline Power unit & 12 & 3 \\
\hline $\begin{array}{l}\text { Hydraulic Transmission } \\
\text { Control }\end{array}$ & 4 & 1 \\
\hline Cabin & 4 & 1 \\
\hline Tractor control & 4 & 1 \\
\hline Electrical equipment & 2 & 1 \\
\hline Support roller & 1 & 2 \\
\hline Blade control joystick & 1 & 1 \\
\hline Fan drive & 1 & 1 \\
\hline Total: & 277 & \\
\hline
\end{tabular}

Next, the Pareto diagram [8] is used, which allows identifying the problematic units and assemblies and distributing efforts to solve problems.

Table 4 shows an example of the representation of the source data for constructing Pareto diagrams. Using Pareto analysis, problematic units and assemblies of the tractor brand under consideration were identified and presented in Figure 8.

The next step is to organize defects as a percentage by complexity groups, Table 5 .

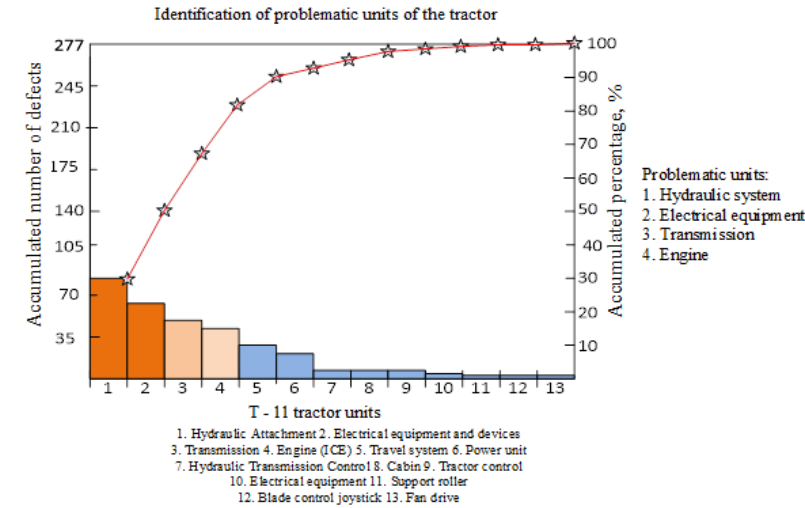

Fig. 8. Identification of problematic units and assemblies using Pareto analysis for $\mathrm{T}-11$ tractors

Table 4. Initial data for constructing a Pareto diagram (identification of problematic units on the example of $\mathrm{T}-11$ tractor)

\begin{tabular}{|l|c|c|c|}
\hline Name of units & $\begin{array}{c}\text { Number } \\
\text { of } \\
\text { defects }\end{array}$ & $\begin{array}{c}\text { Accumulated } \\
\text { number of } \\
\text { defects }\end{array}$ & $\begin{array}{c}\text { Accumulated } \\
\text { percentage, } \\
\%\end{array}$ \\
\hline Transmission & 83 & 83 & 30 \\
\hline $\begin{array}{l}\text { Hydraulic } \\
\text { Attachment }\end{array}$ & 60 & 143 & 51.6 \\
\hline $\begin{array}{l}\text { Electrical } \\
\text { equipment and } \\
\text { devices }\end{array}$ & 45 & 188 & 67.8 \\
\hline Engine (ICE) & 42 & 230 & 83 \\
\hline Travel system & 18 & 248 & 89.5 \\
\hline Power unit & 12 & 260 & 93.8 \\
\hline $\begin{array}{l}\text { Hydraulic } \\
\text { Transmission } \\
\text { Control }\end{array}$ & 4 & 264 & 95.3 \\
\hline Cabin & 4 & 268 & 96.7 \\
\hline Tractor control & 4 & 272 & 98.1 \\
\hline $\begin{array}{l}\text { Electrical } \\
\text { equipment }\end{array}$ & 2 & 274 & 98.9 \\
\hline Support roller & 1 & 275 & 99.2 \\
\hline $\begin{array}{l}\text { Blade control } \\
\text { joystick }\end{array}$ & 1 & 276 & 99.6 \\
\hline Fan drive & 1 & 277 & 100 \\
\hline
\end{tabular}

Table 5. Systematization of defects as a percentage by failure complexity groups

\begin{tabular}{|c|c|c|c|}
\hline \multirow{2}{*}{ Tractor brands } & \multicolumn{3}{|c|}{$\begin{array}{c}\text { The number of defects of various } \\
\text { complexity groups, \% }\end{array}$} \\
\cline { 2 - 4 } & Group 1 & Group 2 & Group 3 \\
\hline $\mathrm{T}-11.01$ & 70 & 15 & 15 \\
\hline $\mathrm{T}-15.01$ & 50 & 25 & 25 \\
\hline$\ldots$ & & & \\
\hline
\end{tabular}

The problematic units and assemblies with most complex defects are determined and characteristic defects and malfunctions for them are identified.

Identified defects are divided into 3 main types:

- constructive;

- production;

- discrepancies of NTD.

In turn, each of the listed defects can be assigned to the group of defects: critical, significant, insignificant. 
Critical and significant defects cause failures of 3 complexity groups:

- complexity group 1 (the most difficult failure difficulty group);

- complexity group 2 (less complex failure group);

- complexity group 3 (simple failure group).

An example of the classification of critical defects is given in Table 6.

The data on typical defects and malfunctions of the third complexity group of problematic units and assemblies of industrial tractors identified during warranty operation are recorded in the failure and malfunction logbook, Table 7.

After the enterprise management learns the information reflecting the status of defects and malfunctions, they draw up a schedule of work on the implementation of various measures to eliminate the identified defects. After bringing the work schedule to the appropriate services, they prepare a draft action plan to improve product quality, which is an annex to the order of the general director of the company to improve product quality. In accordance with this order, all services and departments begin to carry out the planned activities.

Table 6. Classification of critical defects of industrial tractors by complexity groups

\begin{tabular}{|l|l|l|l|}
\hline \multirow{2}{*}{ Critical defects } & \multicolumn{2}{|c|}{ Complexity group } \\
\cline { 2 - 4 } & 1st & 2nd & 3rd \\
\hline $\begin{array}{l}\text { Seizure, knocking, increased noise or } \\
\text { heating of the units during operation, } \\
\text { exceeding the permissible level, which } \\
\text { cannot be eliminated by adjustment } \\
\text { without disassembling or replacing them }\end{array}$ & & & \\
\hline $\begin{array}{l}\text { Leakage of oil, coolants and technical } \\
\text { fluids into sinks, cracks, joints and seals of } \\
\text { units that cannot be eliminated by } \\
\text { tightening }\end{array}$ & & & \\
\hline $\begin{array}{l}\text { Coolant entering the lubrication system, } \\
\text { engine or oil cylinders in the engine } \\
\text { cooling system }\end{array}$ & & & \\
\hline $\begin{array}{l}\text { The oil pressure in the lubrication system is } \\
\text { missing or does not meet the requirements } \\
\text { of TS (over 30 \% of the norm) when } \\
\text { checking with a control manometer }\end{array}$ & & & \\
\hline
\end{tabular}

Table 7. Fragment of the logbook of failures and malfunctions

\begin{tabular}{|l|l|l|l|}
\hline \multicolumn{1}{|c|}{ Name of units } & \multicolumn{1}{|c|}{ Malfunction characteristic } & \multicolumn{1}{c|}{ Cause of malfunction } & \multicolumn{1}{c|}{ Remedy } \\
\hline $\begin{array}{l}\text { 1101-16-2-03SB } \\
\text { transmission installation }\end{array}$ & $\begin{array}{l}\text { Reduced oil pressure in the left } \\
\text { SB due to a cut of 018-022 ring } \\
\text { on the valve }\end{array}$ & $\begin{array}{l}\text { Poor manufacturing of SC and } \\
\text { SB control unit with deviations } \\
\text { from the design documentation }\end{array}$ & $\begin{array}{l}\text { The ring has been replaced. } \\
\text { 313512-15-1SB control unit } \\
\text { replacement is necessary }\end{array}$ \\
\hline $\begin{array}{l}\text { 1101-16-2-03SB } \\
\text { transmission installation }\end{array}$ & $\begin{array}{l}\text { Periodic cut of sealing rings } \\
018-022 \text { on the valves of the SC } \\
\text { and SB 313512-15-1SB control } \\
\text { unit }\end{array}$ & $\begin{array}{l}\text { Poor manufacturing of the SC } \\
\text { and SB control unit with a } \\
\text { deviation of sizes from the } \\
\text { design documentation }\end{array}$ & $\begin{array}{l}\text { Replacing the control unit while } \\
\text { running 299 motor hours }\end{array}$ \\
\hline Engine YaMZ-236ND-2 & $\begin{array}{l}\text { Broken bolt M10-6g 40 mounting } \\
\text { the compressor to the engine }\end{array}$ & Poorly manufactured bolt & Bolt replacement \\
\hline Engine YaMZ-236ND-2 & Engine does not start & Failure of AZF 4581 starter & Starter 2501.3708-01 is installed \\
\hline $\begin{array}{l}\text { Side clutch (SC) and } \\
\text { right stopping brake } \\
\text { (SB) }\end{array}$ & $\begin{array}{l}\text { Reduced pressure in the right } \\
\text { SB }\left(12.5-15 \text { kg } * \text { s/cm }{ }^{2}\right)\end{array}$ & $\begin{array}{l}\text { Incomplete braking of brake } \\
\text { discs due to increased leaks } \\
\text { through the piston seals of SB }\end{array}$ & $\begin{array}{l}\text { Replacing all ring gaskets in SC } \\
\text { and SB }\end{array}$ \\
\hline $\begin{array}{l}\text { Electrical equipment } \\
1101-10-1 S B\end{array}$ & $\begin{array}{l}\text { Front window wiper does not } \\
\text { function }\end{array}$ & Failure of gear motor 525.3730 & Gear motor replacement \\
\hline
\end{tabular}

\section{Conclusion}

From the point of view of improving the quality and reliability of manufactured equipment it is important to organize at the enterprise a system for collecting and processing information on the reliability of manufactured products.

The system of collecting and processing information on reliability makes it possible:

- to identify structural and technological defects of the product, reducing its reliability, as well as deficiencies in the organization of repair and operation;

- to install elements and components that limit product reliability;

- to specify failure criteria and spare parts consumption rates;

- to evaluate the effectiveness of measures to improve the reliability of products.

\section{References}

1. S.G. Stopalov, Collection and processing of information to assess reliability in a real situation, Agricultural machinery: maintenance and repair, 4, 37-47 (Panorama, Moscow, 2017)

2. A.M. Plaksin, A.A. Gulyarenko, Comparison of reliability parameters of domestic and imported tractors in ordinary operation, Herald of ChSAA, 57, 126-132 (Chelyabinsk, 2010)

3. V.V. Kachurin, A.M. Plaksin, Restoring the capacity of machine-tractor units with mobile links, Herald ChSAA, 58, 134-136 (Chelyabinsk, 2011)

4. M.N. Kostomakhin, A.N. Voronov, Ya.E. Rubtsova, Analysis of reliability parameters of tractors according to a machine test station, Agricult. Machin. Mainten. and repair, 2, 43-51 (2014)

5. Monitoring the reliability of high power tractors for the village, Retrieved from: 
https://os1.ru/article/4969-monitoring-nadejnostitraktorov-vysokoy-moshchnosti-dlya-sela

6. M.N. Kostomakhin, A.N. Voronov, Model of the device for collecting information about the reliability of equipment, Proc. of GOSNITI, 130, 115-119 (2018)
7. M.N. Kostomakhin, A.N. Voronov, Collection of information on the reliability of agricultural machinery in operation, Agricultural machinery: maintenance and repair, 5, 51-55 (Panorama, Moscow, 2018)

8. S.A. Zaitsev, ed., Quality management, textbook (KNORUS, Moscow, 2018) 